\title{
Information Flows in Transformation and Change Management Supporting Models
}

\author{
Radosław Lipiński
}

\begin{abstract}
Purpose/Thesis: The purpose of this article is to analyze the use of the information flow perspective in existing, popular models that support transformation and change.

Approach/Methods: The author identified the concept of information flows and the criterion for evaluating transformation models. He analyzed (evaluated) five of most popular contemporary models supporting transformation process managment.

Results and conclusions: Using the perspective of information flows in change processes can improve the efficiency of the transformation process. Currently used models support this area in a very limited manner.

Practical implementation: The results of the analysis can be used to build a practical change supporting model based on information flows and method to evaluate transformation models.

Originality/Value: Defining the concept of information flows in the domain of change and transformation. Conducting research on existing transformation models from information process perspective.
\end{abstract}

Keywords

Information flows. Process. Transformation. Change. Model evaluation.

Received: 21 May 2017. Reviewed: 19 July 2017. Accepted 28 August 2017.

\section{Introduction}

Change is something that accompanies man perpetually from birth to death, practically in every aspect of life. Governing changes and transformations is a key area for managing organizations. One of the subject's researchers, in his considerations, summarized it in the following words: "It is evident from this article that change is an ever-present element that affects all organizations. There is a clear consensus that the pace of change has never been greater than in the current continuously evolving business environment. Therefore, the successful management of change is a highly required skill" (Todnem, 2005, 378). The above is confirmed by data provided by Hany Wells regarding further development of project management methods, so called Project Management Methodologies:

Since 1999, PMMs are firmly placed as one of the top ten contributing factors towards project failure, according to the Standish Group (2010). In the 2008 version of the CHAOS report, it was stated that although improvements in the rate of project success (35\%) are obtained, the rate of failure (19\%), and challenged (46\%) project performance remain at levels that deserve further attention (Wells, 2012).

Organizations that possess the ability to make effective changes, build stronger and more efficient structures (organizational, business, personal and social), and are capable of using them in an ever-changing environment. 
This article attempts to analyze how information processes and its flows affect change processes, and how they are supported in the existing transformation management models. Information processes remain simultaneously the object and the subject of transformation. Having taken into account to what extent change and its effective management affects our reality, including the dimension of the flow of information to the scope of the discussion might prove beneficial to analyzing this topic.

\section{Information Flows - definition and criterion}

The concept of information flow in contemporary world has been frequently used in different contexts and meanings. However, before we attempt to define it, let us consider the very concept of information. Its unequivocal definition is still subject to numerous discussions. The concept itself has many meanings on various levels. The philosopher, Professor Marek Hetmański, sums it up in an interesting manner:

Information, since it is not a concrete thing, does not take a uniform shape, nor is it homogeneous;
it can be recognized in many things. It has the nature of a relational event. In abstract terms, it takes
the shape of an opportunity which is realized in specific situations, in the actions of systems of things
and processes occurring in particular situations. Somehow it always "operates", "does" something
particular which brings various results and effects. [...] It is present in these aspects of reality, where
some difference marks its presence, and manifests itself where concrete action and change take place.
It is not present in unchanging continuity and stagnation, although it is potentially rooted everywhere
as a form ready to communicate and interact. It has a causative and dynamic nature. It applies equally
to the physical and natural world as well as to human and social matters (Hetmański, 2013, 15). ${ }^{1}$

For the purpose of this paper, a detailed analysis of this concept will not bring additional value, but it is important to understand how wide topic it is.

Let us return to the discussion on the question of information flows. At times the use of this term refers to the description of the process of communication between people, and sometimes concerns the flow of information in a wider sense. This concept may also be encountered in connection with knowledge flows. It is used in the context of various information processes, including IT, logistics and medicine. It is reflected perfectly in the results of using the Google Scholar search engine. The enquiry of the term "information flow" performed on September 10th, $2016^{2}$ returned articles and works from the categories mentioned by the author. The query conducted in Polish ${ }^{3}$ revealed that the understanding of the very concept of information flow as well as the variety of responses were equally high, but the returned categories were different: business communication, organization management, philosophy, logistics, quality management, etc. Undoubtedly, enquires in both languages have shown a very broad understanding of this concept and its applicability in many areas.

Bearing in mind the gravity of this concept for the thesis of these considerations, participants in qualitative research - seven experienced managers and leaders of organizations

\footnotetext{
1 Translation from Polish.

${ }^{2}$ https://scholar.google.pl/scholar?q=information+flow\&btnG=\&hl=pl\&as_sdt=0\%2C5\&as_vis=1

${ }^{3}$ https://scholar.google.pl/scholar?hl=pl\&as_sdt=0,5\&as_vis=1\&q=przep $\%$ C5\% $82 y w+i n f o r m a c j i$
} 
(the qualitative research conducted by the author of this article is described in more detail further) - were asked to provide their definitions of the term information flows. The received answers are listed in the Table 1.

Tab. 1. Definitions of qualitative research respondents regarding

the term information flow (own data, based on the results of qualitative research, 2016)

\begin{tabular}{|l|l|}
\hline Respondent 1 & \begin{tabular}{l}
\multicolumn{1}{c|}{ Definition of the term: information flow } \\
the wall of the cave. The flow of information in an organization reflects the way \\
people communicate with each other.
\end{tabular} \\
\hline Respondent 2 & $\begin{array}{l}\text { Passing knowledge or expectations in organizational structures in different } \\
\text { directions, from one place of an organization to another, from one point to } \\
\text { another. }\end{array}$ \\
\hline Respondent 3 3 & $\begin{array}{l}\text { Most frequently with silo mind-set, that is, with top-down information transfer, } \\
\text { and in instances when we talk about passing information between two separa- } \\
\text { te silos, going through the top to reach down again. There is also a horizontal } \\
\text { information transfer, and it is relatively uncommon in organizations, but more } \\
\text { efficient and prompt. }\end{array}$ \\
\hline Respondent 4 & $\begin{array}{l}\text { First, the flow of information in organizations is the flow of information from } \\
\text { top to bottom and from bottom to top. We can also talk about the flow of hori- } \\
\text { zontal information, which is not as crucial as well-structured communication } \\
\text { - from top to bottom and from bottom to top. }\end{array}$ \\
\hline Respondent 5 5 & $\begin{array}{l}\text { This is the most important aspect, the basic factor when it comes to the ability } \\
\text { to accomplish anything, any given project. It seems to me that among the } \\
\text { people involved in project implementation, the truly involved ones, the lack of } \\
\text { information flow between them may lead to tremendous difficulties in project } \\
\text { realization. I am not saying that it makes it impossible, but quite difficult. }\end{array}$ \\
\hline Respondent 7 & $\begin{array}{l}\text { They are verbal, written, computer, emotional means of communication of } \\
\text { information from man to man, from machine to man, from man to machine, or } \\
\text { machine to machine. } \\
\text { tion concerning not only the organization, but also important aspects of the } \\
\text { performed tasks. }\end{array}$ \\
\hline Respondent
\end{tabular}

The answers gathered are already more convergent and located within the area of the organization, its structures, its flow directions, and its components. Respondents' definitions allow to give direction to the understanding of the concept of information flows and link them with the subject of the article (change, transformation, information processes). In the context of the above article, we shall define the concept of information flows that will be used for its purposes. Information flow is to be understood as a process in which information (whatever form it shall assume) propagates in an environment and affects the future state of this environment.

The concept of the environment used in the aforementioned definition needs to be understood as a combination of three elements, which are: (1) people together with their personalities (emotions, motivations, beliefs, experiences, etc.), and relationships between 
them; (2) environment-specific static structures - for the purposes of this paper, they will be organizational structures such as: teams, groups, subgroups, departments, etc.; (3) defined and undefined processes occurring in the environment - information, business, communication, legal, administrative, IT, etc.

What is of particular vitality in information flows and transformations is the fact that while considering flows in a given change, the process has to be perceived holistically, with the emphasis on the aspects of the process, the environment, the human factors as well as the relationships in which all of the above is taking place, additionally taking into account the final result of the transformation. The abovementioned holism can be compared to the system concept and information flow in a system that is undergoing changes. Since the focus of this work is on organizations and people, the sociological approach seems most appropriate:

The concept of a system entails a complex whole, consisting of many elements interconnected by mutual relations and separated from the external environment by a clear boundary. The apparent examples of systems are living organisms, but also: molecules, buildings, planets, galaxies. Such a general concept can be applied to the analysis of society at various levels of generality (Sztompka, 2005, 20).

\subsection{Assessment of the support of information flows by transformation models}

Another question might be posed here of how to evaluate models for managing transformational processes in relation to their support to information flows. It needs to be stressed that the field of change management is characterized by limited maturity of research standards. The research is focused on discovering new concepts, not on building solid foundations and structures that can serve as means of assessing and analyzing already existent knowledge. This proposition was made by Barends and others in 2013 research:

\footnotetext{
This review indicates that the field's research is limited by the dominance of one-shot studies and seldom addresses the same intervention more than once. As this may be appropriate for a field where theory is nascent and topics have attracted little research, it is unacceptable for a mature field with a research tradition of $50+$ years. The field's lack of replication is particularly disturbing. (...) Research activities in OCM seem to be isolated, unrelated, and fail to build on previous studies. Instead, the pursuit of novelty in research, the development of new conceptual frameworks, and the pursuit of new-fangled constructs appear to drive the research agenda. As a result, we know increasingly less about more (Barends et al., 2013, 17).
}

Therefore, let us propose a model evaluation criterion that can be used to answer the question of how a particular model supports the management of flows during the transformation.

Organizations can be perceived as a set of units and various types of groups (operating in the environment of information processes). Between these elements a continuous flow of information occurs. The basic channels in interpersonal interaction are the existing relationships between individuals. At the group level, its members build a particular group culture, which is related to possessing a common vision of the world and a specific language. The above leads to a situation in which information flows are not just mere relationships between people, but also relationships between groups (at different level). This complexity of interaction is presented in the Figure 1. 
Fig. 1. The model of communication flows through relationships within an organization

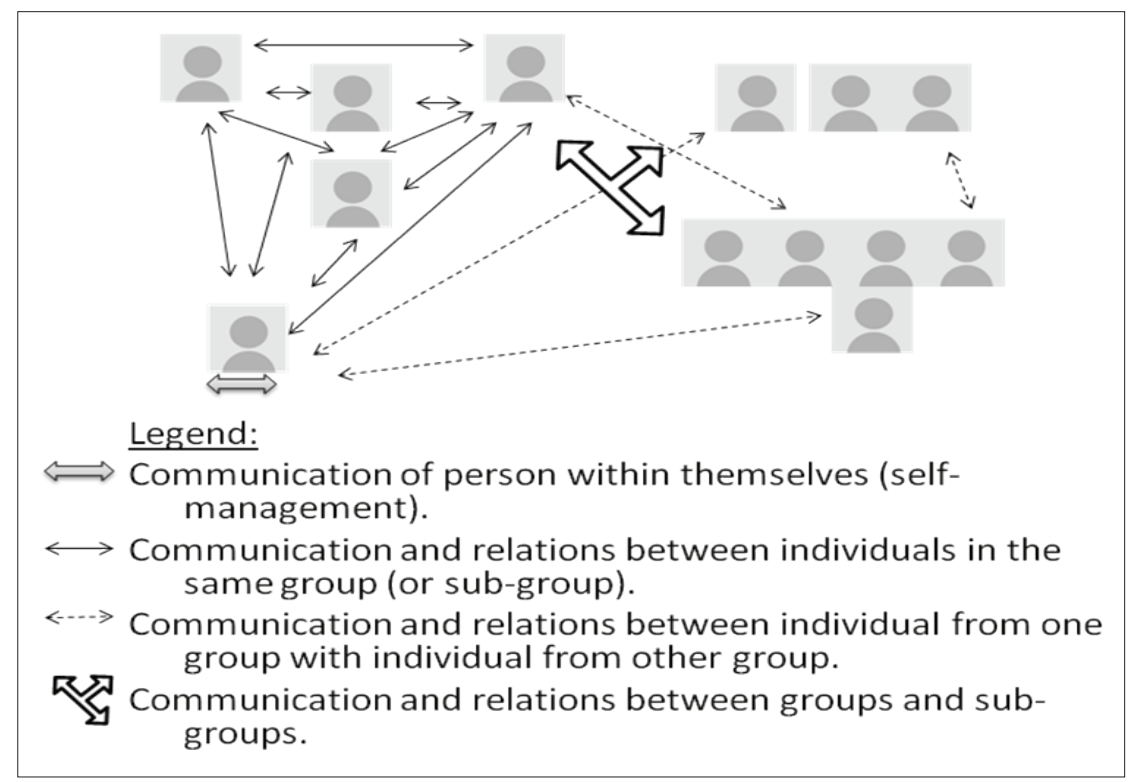

According to research results from IBM (2008) which involved 1,500 people implementing in-company changes in 21 industries, only $41 \%$ of the changes can be considered successful. While conducting this study, it appeared that people and communication remained decisive factors of success. The literature is abundant with instances of works that tie the success of transformation to the efficiency of communication (Kotter, 1994; Mulcahy, 2009; Wagner, 2016). The findings of this study demonstrate how crucial the appropriate management of relationships and communication flows are to the success of performing transformation. There are numerous volumes describing how to increase efficiency in managing communication and influencing others (Cialdini, 2001; Cialdini et al., 2008; Grenny et al., 2013). Including these tools and techniques in a transformational model is very helpful in moderating flows and improves the effectiveness of performance. It needs to be mentioned that at present the factor of relationships and its use for the benefit of the organization is so important for operating in complex structures that it has been introduced into everyday corporate life as one of the official development elements for employees (so-called "networking"). It is often treated equally with other "conservative" skills development, and sometimes regarded as being even more important.

After these initial considerations about information flows and transformations within an organization, let us attempt at the definition of the criterion itself. A transformational model which has inherent structural mechanisms for supporting information flow management (communication and relations) should be the model better assessed by this criterion. Assessments that may be in use for a given criterion are related to the answer to question whether the model supports the management of communication flows. They may take on values: no (1), partial (2), yes (3). A detailed definition of ratings can be found in the Table 2. 
Tab. 2. Detailed assessment levels for the information flow criterion

\begin{tabular}{|l|l|}
\hline Final assessment result & \multicolumn{1}{c|}{ Definition } \\
\hline $\begin{array}{l}\text { yes (3) } \\
\text { (best result, expected) }\end{array}$ & $\begin{array}{l}\text { The model in the majority of its components includes support for } \\
\text { communication flows. It provides tools and techniques directly, and } \\
\text { makes it easy to use tools and techniques existing outside of this } \\
\text { model. }\end{array}$ \\
\hline partially (2) & $\begin{array}{l}\text { The model partially include support for communication flows. It } \\
\text { might provide some tools and techniques directly, or make it easy to } \\
\text { use tools and techniques that exist outside of this model. }\end{array}$ \\
\hline no (1) & $\begin{array}{l}\text { The model provides little or none support for communication flows. } \\
\text { It does not propose tools or support techniques. }\end{array}$ \\
\hline
\end{tabular}

\subsection{Validation and verification of the proposed criterion}

For the validation of the criterion, an in-depth interview (IDI) method has been selected, commonly referred to as casual interview. It belongs to a set of qualitative measures used in social research:

Qualitative interview is the interaction between the interviewer and the respondent. The interviewer is in possession of a general plan of the research which is not a specific set of questions that need to be asked in particular order with specific words (Babbie, 2013, 242).

This particular method allows the researcher to obtain information and feedback from people who participate in the processes under investigation, or have the knowledge regarding their functioning. In this study, the selection of respondents was of particular importance. Seven persons from different organizations were selected, all with diverse experience, different age, and professional history. What all respondents had in common was their great commitment and experience in the processes of change and transformation. The interviews were conducted in the second quarter of 2016 in Warsaw by the author of the article.

The criterion for evaluating the perspective of information flows received raving reviews from respondents. In additional questions section, virtually all the respondents mentioned how crucial the role of the management of communication flows in the transformation was. The question regarding the competence that influences effectiveness in the current role best got the following answers: communication, understanding people, psychology, ability to cooperate in a group and team. Communication - this is the key to success in dispersed, international organizations where project teams through which projects are implemented, as well as customers are scattered all over the world and in all time zones. Communication is definitely the key. Half of the respondents mentioned the criterion of communication support in response to a question regarding their own favorite indicator of transformational models.

Interestingly enough, several respondents tied the area of information flows with cultural or emotional factors, an exemplary quote: 
Communication is key. For me, these two elements [culture, emotions] belong to the component of communication and relationships. You have verbal, non-verbal communication, it evokes certain emotions, and you have to manage that as well. For me, it's still part of communication, the way you communicate, it gives rise to other emotions depending on the culture, the society, the place where one was raised.

Summarizing, the criterion for information flows was evaluated well during interviews. In the additional questions section, practically all respondents emphasized how crucial the role of the information flow management during transformation was, which was reflected in the quotations. It clearly displays that the respondents confirmed the nature of the influence of the information flow factor in the transformation processes.

Moreover, the accuracy and validity of the use of information flows in evaluating transformation models were confirmed in the quantitative study. The quantitative study is defined as

numerical representation and processing of data to describe the phenomena that this data concerns (Babbie, 2013, 544).

It was completed by the author in August-September 2016 with the aid of the online survey tool ${ }^{4}$. The questionnaires had been sent to about 200 people (excluding those who had participated in qualitative research), who participate in transformational processes (performing managerial and expert roles) in their organizations in Poland. 134 different people completed the questionnaire in full, and only these complete results were taken into account in the final analysis. In this study, the criterion of information flows, on a scale of 1 to 5 ( 5 is maximal mark), was assessed on an average of 3.74. The median of responses was $4.89 \%$ of the respondents gave positive answers to this criterion (values 5 and 4 ). The Figure 2 presents the histogram of the breakdown of respondents' ratings.

Fig. 2. Histogram of numerical results for the criterion

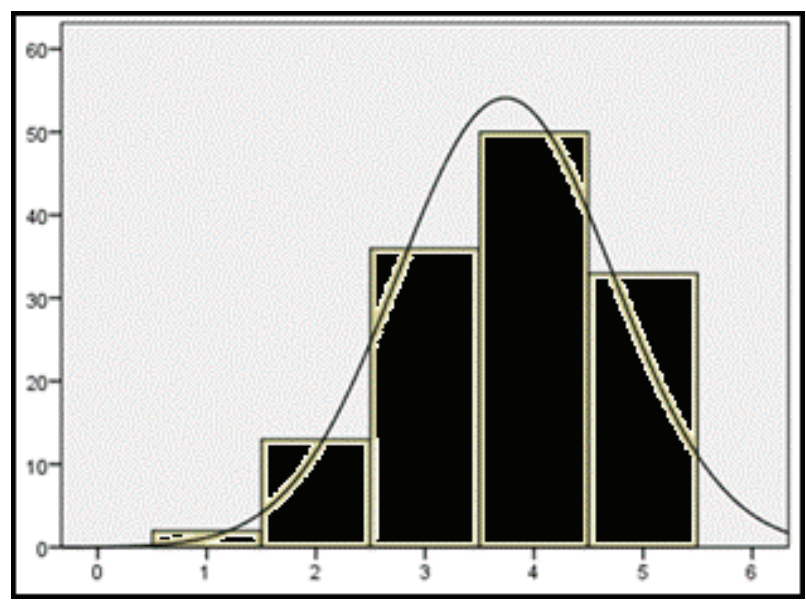

\footnotetext{
4 The survey was conducted using an online tool https://www.limeservice.com/en/
} 


\section{Transformation landscape}

Transformation and change remain an enormous interdisciplinary field that embraces many issues, concepts and models that support operating in this environment. One can distinguish many possibilities of deconstructing and analysis of this sphere. Despite the large number of materials and papers available in contemporary information resources, it is difficult to pinpoint a single, universally accepted taxonomy for the problem. Due to the sheer scale of the environment of ongoing changes, the mere attempt to create such a description reaches far beyond the scope of this work, and remains a matter for separate considerations and analysis.

However, while analyzing available literature, one may encounter some holistic studies describing change and transformation which propose the division into the following areas: unit, team, organization, leadership (Cameron \& Green, 2015, 7). Other studies analyzing transformational models from the perspective of their application in the organization, reveal the division built on management levels, i.e. the area of the strategy of an organization, tactical and, finally, operational (Assen et al., 2014, 1, 81, 193). One may also find studies that propose entirely different divisions (Todnem, 2005).

While defining areas, one must certainly take into account the environment from the perspective of organizations of different types. Having entered company, corporate or non-profit organization field, three main areas of operations can be established:

- complex and well-structured transformation processes - projects, programs, and their portfolios;

- delivery of services, that is execution of processes that continuously transform the organization's resources into defined vale for customers and users;

- maintaining and developing the information and knowledge resources of an organization which in contemporary world is, in the majority of cases, reduced to data, systems and IT infrastructure.

These three areas of activity refer directly to the transformational model groups used in organizations, and are consistent with organizational hierarchies, functions, or development paths common in companies. However, this division appears to be considerably technocratic and disregards the enormous area of transformation processes existing in the holistic understanding of the environment - meaning the transformational processes in individuals and groups of people that take place within the organization, as well as outside, in the society. Therefore, the definition of these areas typical for complex organizational structures needs to be extended by two further areas:

- transformation processes that take place at the level of individuals and the environment which can be called human management in change (task);

- transformational processes occurring in groups of people (models focused on human factors).

These two areas coherently expand our perspective and provide an assessment of transformational models in broadly understood (holistic) transformational areas. 


\subsection{Choice of model representatives in defined areas}

Having defined the transformation areas, the representatives of transformation models need to be chosen. Each area will identify one model that can be considered the most popular. Let us assume that popularity, understood as the end-user's desire to use it, is the final measure of the usefulness of transformation model used by users in a given area of the environment. It is presumed that the desire of individuals (or organizations) to spend their time and money to learn about and use the model is a good indicator that the model is useful to them. This is based on the premise "I invest because it brings me a profit".

Another question is how to choose a model among those currently functioning on the market in a particular area. Let us use the method of triangulation for the purpose, defined as the method of utilizing data and research methods from various sources (both quantitative and qualitative), so that the results are analyzed in a broader perspective and reduce measurement errors (Olsen, 2009,3). The input data for selecting models will come from several sources such as:

- the number of certified professionals active on the market (certificates of the same difficulty level when several of them appear in the models);

- the number of members of the official expert groups associated with the particular transformation models on the professional community website ${ }^{5}$.

The data collected from these sources can be found in the Table 3. The models (candidates) used in the table were selected by the author on the basis of literature research and discussions with transformation practitioners.

Having analyzed and taken into account the results from the sources, the models ranked (Tab. 3) first in their category were selected for further analysis. These models are: PMBOK, ITIL, TOGAF, SLII, Kotter -8 steps of change management. Next section contains more information about chosen models.

\section{Transformation models and their evaluation for information flows support}

The main purpose of this section is to evaluate five selected transformation models from the perspective of their support of information flows in the change. Therefore, a very general description of each model is provided. In order to fully understand the analyzed models, the indicated sources need to be consulted.

\section{1. $Р М В O K$}

PMBOK is the official name of the currently most popular project management model. The main principles of the model are described in the book Project Management Body of Knowledge (commonly referred to as PMBOK). The model described in the PMBOK book has been created and is being developed by the Project Management Institute (PMI). The

\footnotetext{
${ }^{5}$ Based on www.linkedin.com . This social network for professionals has 450 millions of users (information from July 2016).
} 
PMI proposal is a set of good practices in project management, the use of which increases the likelihood of the success of the performed change (PMI, 2013).

Tab. 3. Data regarding market transformation models in the defined areas

\begin{tabular}{|c|c|c|c|}
\hline Name of the area & $\begin{array}{c}\text { Transformation } \\
\text { Model }\end{array}$ & $\begin{array}{l}\text { Number of expert } \\
\text { group members } \\
\text { at linkedin.com }{ }^{1}\end{array}$ & $\begin{array}{c}\text { Number of certified } \\
\text { specialists }^{2}\end{array}$ \\
\hline \multirow{3}{*}{$\begin{array}{l}\text { Complex and well- } \\
\text {-structured transfor- } \\
\text { mation processes }\end{array}$} & $\begin{array}{l}\text { Project Management } \\
\text { Professional (PMP) }\end{array}$ & $\begin{array}{l}\text { PMI } 202000 \\
\text { PMP } 82000\end{array}$ & $\begin{array}{l}\text { PMP - approximately } \\
713000\end{array}$ \\
\hline & Prince 2 & $\begin{array}{l}\text { OGC - none } \\
\text { Prince2 } 13500\end{array}$ & $\begin{array}{l}\text { Prince } 2 \text { Practitioner } \\
\text { - lack of data }\end{array}$ \\
\hline & Scrum & $\begin{array}{l}\text { Scrum Alliance - } \\
46000 \\
\text { Scrum - } 75000\end{array}$ & $\begin{array}{l}\text { Scrum PSM II and III } \\
\text { - approximately1000 }\end{array}$ \\
\hline \multirow{4}{*}{ Delivery of services } & $\begin{array}{l}\text { Information Techno- } \\
\text { logy Infrastructure } \\
\text { Library (ITIL) }\end{array}$ & $\begin{array}{l}\text { ITIL Service Manag. } \\
-153000 \\
\text { ITIL }-75000\end{array}$ & $\begin{array}{l}\text { ITIL Foundation - } \\
\text { over } 1500000\end{array}$ \\
\hline & $\begin{array}{l}\text { Microsoft Operations } \\
\text { Framework (MOF) }\end{array}$ & MOF V4 - 300 & Lack of data \\
\hline & ISO/IEC 20000 & ISO $20000-4000$ & Lack of data \\
\hline & $\begin{array}{l}\text { Control Objectives } \\
\text { for Information and } \\
\text { related Technology } \\
(\text { COBIT }) \\
\end{array}$ & COBIT - 18000 & Lack of data \\
\hline \multirow{3}{*}{$\begin{array}{l}\text { Maintaining and de- } \\
\text { veloping the informa- } \\
\text { tion and knowledge } \\
\text { resources }\end{array}$} & $\begin{array}{l}\text { The Open Group Ar- } \\
\text { chitecture Framework } \\
\text { (TOGAF) }\end{array}$ & TOGAF - 34000 & Certified - 40868 \\
\hline & $\begin{array}{l}\text { Microsoft Solutions } \\
\text { Framework (MSF) } \\
\end{array}$ & Lack of group & Lack of data \\
\hline & $\begin{array}{l}\text { Federal Enterprise } \\
\text { Architecture }\end{array}$ & FEAF - 500 & Lack of data \\
\hline \multirow{2}{*}{$\begin{array}{l}\text { Transformation } \\
\text { processes that take } \\
\text { place at the level of } \\
\text { individuals }\end{array}$} & $\begin{array}{l}\text { Situational Leader- } \\
\text { ship II (SLII) }\end{array}$ & $\begin{array}{l}\text { Situational Leader- } \\
\text { ship }-3500\end{array}$ & Lack of program \\
\hline & Virginia Satir model & Lack of group & Lack of program \\
\hline \multirow{3}{*}{$\begin{array}{l}\text { Transformational } \\
\text { processes occurring } \\
\text { in groups of people }\end{array}$} & $\begin{array}{l}\text { Kotter } 8 \text { steps of } \\
\text { change }\end{array}$ & $\begin{array}{l}\text { Change Management } \\
\text { Practitioners }-8000\end{array}$ & Lack of program \\
\hline & $\begin{array}{l}\text { Lewin, 3-step model } \\
\text { (defrost, change, } \\
\text { freeze) }\end{array}$ & Lack of group & Lack of program \\
\hline & Sange System Model & Lack of group & Lack of program \\
\hline
\end{tabular}




\subsection{ITIL}

ITIL (Information Technology Infrastructure Library) is a service management model developed by a government agency (Central Communications and Telecommunications Agency) in the United Kingdom. Its first version was published in 1989. The third version of the library is currently in use. This model was built for IT services, but most of the features proposed in this model can be successfully applied to other types of services as well. The ITIL model is not intended solely for managing transformations (it covers a much larger scope). However, the management of service transformation and change is an important part of the ITIL model (one of the five parts of the ITIL library is devoted to this topic) (TSO, 2007).

\subsection{TOGAF}

TOGAF (The Open Group Architecture Framework) is a model designed to manage the Enterprise Architecture. The TOGAF has been prepared and is being developed by the Open Group consortium. TOGAF introduces methods for: design, planning, implementation and maintenance of architecture. It is a model that describes chiefly the field of information architecture but transformation management remains one of the most important parts of this model. What is of vital importance is that TOGAF considers the transformation from the perspective of the organization's architecture (including information architecture) (TOGAF, 2011).

\subsection{Situational Leadership (SLII)}

Another model chosen for the analysis is Ken Blanchard's situational leadership model (also known as Situational Leadership II). This model is used to manage employees in tasks. However, this model has no limits regarding the size of the tasks which may be different types of changes and transformations. The final version of SLII was presented by Ken Blanchard in the early 1980's. Since then, it has been successfully implemented in many organizations of various types (Blanchard, 2009).

\subsection{Kotter - 8 steps of managing change}

The 8-step change management model was created by John Paul Kotter. It was initially described in the book Leading Change (Kotter, 1994). The model was created as a result of the analyses of numerous transformations performed in different organizations. Kotter began with the definition of the most common reasons for the failure of transformation, and, using it as the foundation, crafted a model that counteracts these causes. After the publication, the model gained considerable popularity among managers of organizational change, and was intensively developed at a later stage (Kotter, 2012; Kotter et al., 2006).

\subsection{Assessment of described models with the proposed criterion}

After a brief description of selected models, it is vital to analyze how they support the information processes that take place during the transformation. For this purpose the proposed criterion will be used, accompanied by the defined rating scale. 
The PMBOK model does not directly describe the manner of how to manage communication flows and relationships during the transformation. However, some prominent tools and mechanisms existing within this model support the abovementioned areas. The first one is process-based design of the model constructed, and information flows between these processes. Many existing processes indirectly support the flow of information. The above phenomenon is particularly evident in the project initiation phase, and in the artifacts related to the completion of certain processes. An adequate example is a project charter or a communication plan. The second mechanism includes the knowledge areas existing in the model: communication management and stakeholder management. These knowledge areas contain tools that are strongly associated with information flows for communication and relationships, and their use increases the efficiency of the flows. Taking into account the abovementioned elements, the PMBOK model was assessed in the criterion: partially (2).

ITIL has a couple of in-built mechanisms which support the information flows processes. These mechanisms are primarily comprehensive definitions of roles for particular processes and services. Their scope of responsibilities includes communication and building relationships with relevant stakeholders of the process and services. In addition, an essential element in the life cycle of Service Operation is communication and establishing relationships with the client (e.g. special request type - request for information, customer response requirement within allotted time, etc). We must note, however, that these elements are related to processes and, to a smaller extent, to information flows, but they do not support the area of interpersonal relationships which is a key factor in information flows; they are only mentioned in the transition lifecycle (dedicated for transformation and change management areas). Taking into account the aforementioned features of this model, we can assume that ITIL describes the area of information flows partially (2).

The TOGAF model transformation does not take into account information flows between transformation participants. Some of the tools and techniques specified in the TOGAF documentation relate to relationships and information flows (such as architectural points of view, stakeholders' concerns, etc), but they are not sufficiently significant for the model to support areas relevant to this criterion. Therefore, the TOGAF rating is: no (1).

The SLII model has some elements that support the concept of information flows. One of these is to clearly define the relationship between the superior (the person delegating the task) and the person performing the task. This mechanism provides the adjustment of appropriate communication and management style between two key sides of change. An additional mechanism is to identify supporting roles in a delegated task. By specifying roles, the manager has to establish appropriate communication and relationship-based channels with these people. Unfortunately, the model does not include other tools supporting the flows, but these two elements allow to evaluate the SLII model in this criterion at the level: partially (2).

The Kotter model to a large extent refers to the management of information flows in transformation. From the very beginning it emphasizes how important it is to make the members of the organization aware of the urgency of change through communication flows and the need to work through appropriate relationships. Step two of the model (create a change coalition) boils down to establishing a strong relationship between the key members of the organization to support transformation. The next steps include a variety of elements and tools to support information flows: creating a collective vision for transforming together 
through the coalition of change, its effective communication, informing about successes, etc. Practically, each of 8 steps displays references to this perspective. Kotter model by criterion can be considered as fully supporting the flow of information in the change. Therefore, the rating given is: yes (3).

Fig. 4. Results of analysis of all evaluated models by information flows criterion

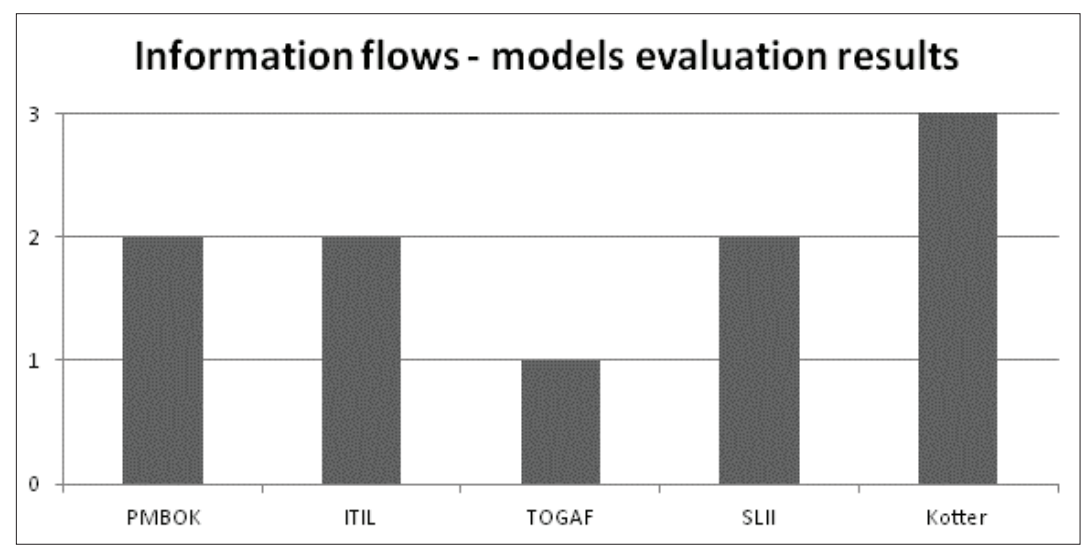

\section{Conclusion}

It needs to be stressed that this article is a unique attempt at analyzing the process of change and transformation from the perspective of information processes, and the unquestionable impact these processes have on the final result of each change. The most vital aspect of this paper was the analysis of models supporting transformation processes, and establishing the extent to which they support the information flow processes that occur during change. The final results of the analysis prove that only one of the models visibly supports information flows. This model (Kotter) is a relatively rarely used in organizations (compared to other models analyzed), and covers an area frequently neglected in everyday life of the enterprise. Other popular and widely used models (PMP, ITIL, TOGAF) do not devote sufficient attention to the question of information flows during change. Important output of this article is the definition of the criterion that allows any researcher to measure to what extend transformation model supports information flow processes in change. Another interesting question to be raised is how moderating flows of information affects the efficiency of transformation processes, and whether a model based on such flows can be created.

\section{References}

Assen, M.; Berg, G.; Pietersna, P. (2014). Key Management Models (2nd edition). London: Financial Timem Prentice Hall.

Babbie, E. (2013). Podstawy badań społecznych. Warszawa: Wydawnictwo Naukowe PWN.

Barends, E.; Janssen, B.; ten Have, W.; ten Have, S. (2013). Effects of change interventions: What kind of evidence do we really have? [online] [03.06.2016] The Journal of Applied Behavioral Science: 
http://www.tenhavecm.com/wp-content/files_mf/barendsetal.2013effectsofchangeinterventions whatkindofevidencedowereallyhave.pdf

Blanchard, K. (2009). Przywództwo wyższego stopnia. Warszawa: Wydaw. Naukowe PWN.

Cameron, E.; Green, M. (2015). Making Sense of Change Management (4th edition). London: Kogan Page Limited.

Cialdini, R. B. (2001). Wywieranie wptywu na ludzi - Teoria i praktyka. Gdańsk: Wydawnictwo Psychologiczne.

Cialdini, R. B.; Goldstein, N. J.; Martin, S. J. (2008). Yes 50 Scientifically Proven Ways to Be Persuasive. London: Free Press.

Grenny, J.; Patterson, K.; Maxfield, D.; McMillan, R.; Switzler, A. (2013). Influencer The New Science of Leading Change. New York: Mc Graw Hill Education.

Hetmański, M. (2013). Epistemologia informacji. Kraków: Copernicus Center Press.

IBM (2008). Making Change Work [online]. IBM [24.07.2016], http://www-07.ibm.com/au/pdf/ making_change_work.pdf

Kotter, J. P. (1994). Leading Change. London: Harvard Business Review Press.

Kotter, J. P. (2012). The Heart of Change: Real-Life Stories of How People Change Their Organizations. London: Unabridged.

Kotter, J. P.; Ratheber, H.; Mueller, P. (2006). Our Iceberg Is Melting. New York: St. Marttin's Press .

Mulcahy, R. (2009). PMP Exam Prep. New York: RMC Publication Inc.

Olsen, W. (2009). Triangulation in Social Research: Qualitative and Wuantitavie Methods Can Really Be Mixed, Dvelopment in Sociology [online]. Association for Progressive Communications [28.07.2016], http://research.apc.org/images/5/54/Triangulation.pdf

PMI (2013). A guide to the project management body of knowledge (PMBOK Guide) (5th edition). Newtown Square: Project Management Institute.

Sztompka, P. (2005). Socjologia zmian społecznych. Kraków: Znak.

Todnem, R. (2005). Organizational Change Management: A Critical Review. Journal of Change Management , 5(4), 369-380.

TOGAF (2011). TOGAF an Open Group standard [online]. The Open Group Architecture [16.04.2014], http://www.opengroup.org/subjectareas/enterprise/togaf/

TSO (2007). Service Transition. London: The Strategy Office.

Wagner, D. N. (2016). Breakin the Project Wave: Understanding and avoiding failure in project management [online]. PM Word Journal 5(1) [21.07.2016], http://pmworldlibrary.net/wp-content/ uploads/2016/01/pmwj42-Jan2016-Wagner-breakin-the-project-wave-featured-paper.pdf

Wells, H. (2012). How effective are project management methodologies. Project Management Journal, 43(6), 43-58.

\title{
Przepływy informacji w modelach zarządzania transformacją i zmianą w organizacjach
}

\begin{abstract}
Abstrakt
Cel/Teza: Celem artykułu jest przeanalizowanie wykorzystania perspektywy przepływów informacji w istniejących, popularnych modelach wspierania procesów transformacyjnych i zmian w organizacjach. Koncepcja/Metody badań: Autor zdefiniował pojęcie przepływów informacji i wskazał kryterium ewaluacji modeli transformacji. Przeanalizował (poddał ocenie) pięć współcześnie najpopularniejszych modeli wspierania procesu zarządzania transformacją.
\end{abstract}


Wyniki i wnioski: Wykorzystanie perspektywy przepływów informacji w procesach zmian może poprawić efektywność procesów transformacyjnych. Obecnie stosowane modele uwzględniają ten obszar w bardzo ograniczony sposób.

Zastosowanie praktyczne: Wyniki przedstawionej analizy mogą być wykorzystane do budowy praktycznego modelu wspierania zmian w organizacjach, opartego na przepływach informacji oraz metody ewaluacji modeli transformacyjnych.

Oryginalność/Wartość poznawcza: Zdefiniowanie pojęcia przepływów informacji w dziedzinie zmian i transformacji w organizacjach. Przeprowadzenie badania istniejących modeli transformacyjnych z perspektywy procesów informacyjnych.

\section{Słowa kluczowe}

Przepływy informacji. Proces. Transformacja. Zmiana. Model ewaluacji.

RADOSEAW LIPIŃSKI holds currently role of Team Manager in one of the global financial institution. Previously he was working in various managerial roles in one of the leading IT corporation. Alumnus of Warsaw University of Technology Faculty of Electronics and Information Technology (MEng in Computer Science) E Production Engineering (Master's degree in Business Management). Certified coach (CoachWise), practitioner and specialist for transformation and change processes.

Contact to the author:

lipinski.radoslaw@gmail.com 